\title{
Retraction
}

\section{Retraction: Jiang et al. Formation of Proto-Kranz in C3 Rice Induced by Spike-Stalk Injection Method. Int. J. Mol. Sci. $2021,22,4305$}

\author{
International Journal of Molecular Sciences Editorial Office
}

check for updates

Citation: International Journal of Molecular Sciences Editorial Office. Retraction: Jiang et al. Formation of Proto-Kranz in C3 Rice Induced by Spike-Stalk Injection Method. Int. J. Mol. Sci. 2021, 22, 4305. Int. J. Mol. Sci. 2021, 22, 11930. https://doi.org/ 10.3390/ijms222111930

Received: 14 July 2021

Accepted: 23 August 2021

Published: 3 November 2021

Publisher's Note: MDPI stays neutral with regard to jurisdictional claims in published maps and institutional affiliations.

Copyright: (C) 2021 by the author. Licensee MDPI, Basel, Switzerland. This article is an open access article distributed under the terms and conditions of the Creative Commons Attribution (CC BY) license (https:// creativecommons.org/licenses/by/ $4.0 /)$.
MDPI, St. Alban-Anlage 66, 4052 Basel, Switzerland; ijms@mdpi.com

The journal and the authors retract the article "Formation of Proto-Kranz in C3 Rice Induced by Spike-Stalk Injection Method" [1] cited above.

Following publication, concerns were brought to the attention of the editors regarding experimental results from [1] that were found to be unreliable, namely: (1) Several sorghum genes were integrated into the rice genome; (2) Sorghum PPDK and PEPCK genes were expressed in the sorghum-rice (SR) plant; (3) Integration of sorghum DNA caused protoKranz anatomy. This has brought about uncertainty regarding the scientific conclusions.

In accordance with our ethics procedures, an investigation was conducted. The authors have not been able to provide a satisfactory explanation for these irregularities and the journal's Editors-in-Chief no longer has confidence in the conclusions of the paper. Therefore, to ensure the addition of only high-quality scientific works to the field of scholarly publication, this paper [1] is retracted and shall be marked accordingly. The authors agree with this retraction.

We apologize to our readership that this went undetected until now.

\section{Reference}

1. Jiang, D.; Wang, F.; Zhang, H.; Gao, W.; Tong, X.; Lv, C.; Chen, G. Formation of Proto-Kranz in C3 Rice Induced by Spike-Stalk Injection Method. Int. J. Mol. Sci. 2021, 22, 4305. [CrossRef] [PubMed] 